\title{
PERAN INSTITUSI PENDIDIKAN TINGGI DALAM PENGEMBANGAN KAPASITAS KOMUNITAS DESA CIBUNTU DALAM PENGEMBANGAN PARIWISATA BERBASIS MASYARAKAT
}

\author{
Oleh: \\ Iis Ismar Pramala \\ Universitas Indonesia \\ (E-mail: izmar.struggle@gmail.com)
}

\begin{abstract}
ABSTRAK
Keberhasilan pembangunan pariwisata ditingkat desa/ lokal tergantung pada kapasitas komunitas setempat. Dalam proses pengembangan, Komunitas lokal perlu untuk melibatkan pihak eksternal yang mampu memberikan kontribusi positif bagi komunitas lokal. Selain sebagai penerima manfaat dan pemangku kepentingan, komunitas atau masyarakat juga sebagai salahsatu peserta yang perlu terlibat sebagai pengguna layanan pendidikan. Komunitas atau masyarakat merupakan salahsatu ruang lingkup praktek umum pendidikan tinggi. Tujuan dari artikel ini adalah untuk mendeskripsikan gambaran mengenai peran institusi pendidikan Tinggi bagi kapasitas intitusi komunitas Desa Cibuntu Kabupaten Kuningan Jawabarat dalam pengembangan pariwisata berbasis masyarakat. Desa Cibuntu dijadikan sebagai studi dalam artikel ini karena berhasil menjadi Desa Wisata dengan melakukan penataan dan perbaikan bekas galian pasir menjadi daya Tarik wisata yang mempesona, menjadikan Desa Cibuntu mendapatkan penghargaan baik tingkat Nasional maupun tingkat Internasional. Dalam proses pengembangan tersebut terdapat peran institusi pendidikan tinggi. Metode yang digunakan dalam penelitian ini yaitu kualitatif dengan jenis pendekatan deskriptif. Temuan lapangan menunjukkan bahwa Institusi Pendidikan Tinggi memiliki peran bagi kapasitas Komunitas Desa Cibuntu dalam pengembangan pariwisata berbasis komunitas melalui peningkatan kesadaran, pemberian informasi, dan pelatihan.
\end{abstract}

Kata Kunci: Institusi Pendidikan Tinggi, Kapasitas Komunitas, Pengembangan Pariwisata Berbasis Masyarakat

\section{ABSTRACT}

The success of tourism development at the village or local level depends on the capacity of the local community. In the process of development, local communities are needed to involve external parties who are able to give positive contribution to local communities. Beside as a beneficiary and stakeholders, the community is also one of the participants that needs to involve as users of educational services circle. Community is one of scope of general training in higher education. The purpose of this article is to describe the role of higher education institution for community capacity of the Cibuntu Village in Kuningan Regency-Westjava Province. Cibuntu Village is used as a location research in this article because of their success be a Village Tourism by managing and repairing a used sand excavation to be a wonderful attraction tourism, put up Cibuntu Village get some awards are both national or international award level. In the development process there are a high role of higher education institution. The method used in this study is qualitative with the type of descriptive approach. The findings show that the higher education institution has some important roles for the Cibuntu Capacity Community in developing tourism based on communities by raising an awareness, giving an information, and training.

Keywords: Higher Education Institution, Capacity Community, Community Based Tourism

\section{PENDAHULUAN}

Dalam konteks pembangunan di tingkat perdesaan atau lokal, menuntut adanya kapasitas komunitas yang mumpuni untuk mencapai tujuan yaitu kesejahteraan. Komunitas dianggap efektif sebagai kelompok sasaran yang harus dikembangkan kapasitasnya, dimana komunitas sebagai pelaku utama pembangunan utuk mencapai output dan outcome berupa kemandirian dan kesejahteraan melalui peningkatan kapasitas
(Maulana, 2013). Proses pembangunan ini perlu melibatkan unsur eksternal yang dianggap mampu menjembatani dan mentransfer pengetahuan baru. Sebagaimana hasil penelitian proyek pembangunan kapasitas masyarakat pedesaan harus mempertimbangkan nilai dari struktur organisasi terbuka yang mengundang keanggotaan yang lebih beragam dari masyarakat (Peter O’Meara, Janice Chesters \& Gil-Soo Han, 2004). 
Selain itu, kapasitas komunitas yang terdapat didalam komunitas harus menciptakan hubungan kerjasama terhadap sistem yang lebih besar dimana komunitas tersebut ikut berperan (Imran, 2012). Demikian, dalam konteks pemberdayaan, komunitas membutuhkan proses pengorganisasian komunitas sebagai pendekatan untuk meningkatkan kapasitas komunitas (Andini, 2013). Lebih lanjut peningkatan kapasitas komunitas/ masyarakat berfokus pada memungkinkan semua anggota komunitas, untuk mengembangkan keterampilan dan kompetensi sehingga dapat mengambil peran lebih besar mengendalikan kehidupan mereka sendiri dan juga berkontribusi terhadap pembangunan lokal yang inklusif (Noya and Clarence, 2009).

Kapasitas masyarakat adalah interaksi diantara sumberdaya manusia, sumberdaya organiasi, dan modal sosial yang ada di dalam komunitas tertentu yang dapat dimanfaatkan untuk memecahkan masalah kolektif dan meningkatkan atau mempertahankan kesejahteraan komunitas yang diberikan (Chaskin, 2001). Sehingga pada uraian diatas, kapasitas komunitas mengacu pada keadaan dimana masyarakat secara bersama-sama berinteraksi untuk mengidentifikasi potensi dan mencari solusi pemecahan masalah untuk mewujudkan kesejahteraan. Kapasitas komunitas setidaknya mencakup beberapa hal berikut: (1) keberadaan sumberdaya (mulai dari keterampilan individu sampai pada kekuatan organisasi untuk mengakses modal keuangan), (2) jaringan hubungan, (3) kepemimpinan, dan (4) dukungan untuk proses partisipasi oleh masyarakat dalam aksi kolektif dan pemecahan masalah (Chaskin, 2001, pg.292-293).

Komunitas Desa Cibuntu dihadapkan pada masalah yang kompleks. Sebelum menjadi seperti saat ini, wajah Desa Cibuntu mengalami perubahan. Memiliki potensi dengan kualitas tanah yang bagus, mendatangkan orang untuk melakukan aktifitas penambangan dan penggalian pasir sampai seluas 2 Hektar. Hal ini mengakibatkan berubahnya tatanan lingkungan yaitu kerusakan lingkungan dan sosial masyarakat sehingga mendorong terjadinya urbanisasi masyarakat Desa Cibuntu ke Kota-kota untuk mencari nafkah.

Atas dampak demikian yang terjadi di Desa Cibuntu tersebut, komunitas Cibuntu perlu bangkit meningkatkan kapasitas mereka untuk melakukan pembenahan, perbaikan, pengembangan dan penataan lingkungan dan lahan Desa Cibuntu yang rusak, karena pada dasarnya setiap komunitas memiliki kapasitas dan modalnya masing-masing, kapasitas komuntas bersifat dinamis karena pengaruh lingkungan internal dan eksternal (Andini, 2013). UNDP (1997) menuturkan pengembangan kapasitas adalah proses di mana individu, organisasi, institusi dan masyarakat mengembangkan kemampuan (secara individu dan kolektif) untuk melakukan fungsi, memecahkan masalah dan menetapkan dan mencapai tujuan. Kapasitas komunitas yang dibutuhkan tidak hanya dilihat dari kemampuan individual saja, tetapi juga kemampuan komunitas dalam memecahkan masalah secara bersama-sama (Maulana, 2013). Dalam hal ini komunitas Cibuntu menunjukkan kapasitas untuk memecahkan masalah lingkungan dan sosial dengan menjaga keberlanjutan lingkungan dan aspek sosial mereka. Kapasitas komunitas berupa tindakan konservasi dan keterlibatan masyarakat sebagai faktor utama dalam menjaga lingkungan dan budaya (Imran, 2012)

Aspek kesehatan masyarakat Desa Cibuntu menjadi perhatian utama penataan dan pengembangan. Kandang ternak yang pada 
awalnya menempel dengan permukiman masyarakat, di pindahkan ke lokasi khusus yang jauh dari permukiman. Selain penataan terhadap kondisi lingkungan dan sosial masyarakat, penataan juga dilakukan terhadap aspek budaya dengan merawat situs-situs leluhur Desa Cibuntu. Dalam hal ini kapasitas sumber daya manusia menjadi kunci utama dalam penataan untuk pengembangan pariwisata di Desa Cibuntu berbassis komunitas. Pentingnya kapasitas sumber daya manusia senada dalam temuan penelitian yang dilakukan oleh Nurcahyono (2017) mengenai gambaran umum kapasitas komunitas yang mencakup modal fisik, modal finansial, modal lingkungan, modal teknologi, modal sumber daya manusia, modal sosial, serta gambaran tentang strategi kapasitas komunitas dalam Pengembangan Pariwisata Perdesaaan.

Upaya komunitas Desa Cibuntu diatas dalam penataan ternyata belum dirasa cukup. Masyarakat menemukan kapasitas mereka masih lemah dalam menjadikan kondisi Cibuntu lebih baik. Berawal dari kepedulian sejumlah mahasiswa Intitusi Pendidikan Tinggi Trisakti yang sedang KKN di Desa Cibuntu, muncul gagasan untuk membangun Cibuntu sebagai Desa Wisata. Ini didasarkan hasil penelitian mahasiswa Pascasarjana Trisakti bahwa Cibuntu memiliki potensi luar biasa kearah sana. Bahwa dalam pembangunan kapasitas komunitas Desa Cibuntu dalam pengembangan pariwisata nyatanya terdapat keterlibatan unsur stakeholder atau pihak eksternal yaitu institusi pendidikan tinggi. Relevan dengan pendapat Samuel Otto (2009) bahwa pengembangan kapasitas adalah proses pembelajaran lokal yang didorong oleh para pemimpin, koalisi dan agen-agen perubahan lainnya yang membawa perubahan dalam faktor sosial politik, kebijakan, dan organisasi meningkatkamenutn kepemilikan lokal, efektivitas dan efisiensi sebagai upaya untuk mencapai pembangunan tujuan. Morrison (2001) menuturkan bahwa pembelajaran adalah tujuan dari pengembangan kapasitas untuk mengurangi ketidatahuan dan ketidakpastian, dan mengembangkan kemampuan yang dibutuhkan untuk beradaptasi menghadapi perubahan. Dalam hal ini, institusi pendidikan memiliki peran penting bagi keberlanjutan kehidupan di komunitas Desa Cibuntu. Sebagai pelaku perubahan dalam pengembangan masyarakat, institusi Pendidikan tinggi berperan sebagai enabler dalam diskursus komunitas (Adi, 2013).

Lingkup komunitas sangat problematis, dan dari banyak definisi yang telah dikemukakan hanya sedikit yang memiliki kesamaaan (Bell and Newby; Jim Ife, 2008). Komunitas sangat erat kaitannya dengan kehidupan masyarakat dan bagaimana perilaku masyarakat itu nampak, sehingga tindakan komunitas biasanya berbasis pada identifikasi kebutuhan mereka sendiri. Komunitas dapat dianggap sebagai alternatif kelembagaan masyarakat yang memiliki apa yang dicita-citakan atau diharapkan bersama diantara masyarakat. Dalam proses kehidupan, komunitas dapat berinteraksi dengan sesamanya, saling memelihara, berbagi peran dan tanggungjawab secara adil dan semua berpartisipasi dalam pengambilan keputusan untuk mencapai tujuan pembangunan. Dengan demikian lingkup komunitas sangatlah kompleks dan syarat akan permasalahan.

Tidak jarang pentingnya peran pendidikan masuk kedalam ruang lingkup komunitas karena komunitas dihadapkan pada sulitnya memecahkan masalah mereka secara personal jika tanpa bantuan dan kontribusi dari pihak lain. Berdasarkan uraian diatas, komunitas/ masyarakat merupakan 
salahsatu entitas yang perlu juga mendapatkan layanan pendidikan, sebagaimana uraian World Bank Education Strategy 2020 disebutkan bahwa dalam sistem pendidikan, komunitas ditinjau sebagai penerima manfaat dan pemangku kepentingan. Komunitas atau masyarakat juga sebagai salahsatu peserta yang perlu terlibat sebagai pengguna layanan pendidikan/ pembelajaran.

Munculnya upaya identifikasi kebutuhan oleh komunitas atau masyarakat, mengisyaratkan terdapat masalah yang perlu untuk diatasi. Bantuan atas pemecahan permasalahan dapat berasal dari internal maupun dari eksternal yang mumpuni dalam bidangnya. Pihak eksternal inilah bisa berupa bantuan dari keterlibatan institusi Pendidikan.

Merujuk pada permasalahan komunitas Desa Cibuntu diatas, nampak bahwa peran institusi pendidikan telah memberikan bantuan berbasis pengetahuan dan bentuk pengembangan kapasitas bagi komunitas Desa Cibuntu berupa membangkitkan kesadaran komunitas Desa Cibuntu akan potensi wisata yang dimiliki dan kebutuhan untuk melakukan pembenahan terhadap masalah yang ada. Menurut Anthony D. Cortese (2003) Pendidikan tinggi memiliki moral yang mendalam berupa tanggung jawab untuk meningkatkan kesadaran, pengetahuan, keterampilan, dan nilai-nilai yang dibutuhkan untuk menciptakan masa depan yang adil dan berkelanjutan. Selain itu, memahami cara menciptakan masyarakat yang adil dan berkelanjutan harus menjadi prinsip fundamental dalam semua pendidikan. Pendidikan tinggi yang sukses bagi komunitas yaitu mereka yang mampu melakukan kemitraan, memberikan pembelajaran, manfaat dan kontribusi positif bagi komunitas dalam proses pembangunan dan keberlanjutan komunitas. Peran institusi Pendidikan tinggi dalam kaitannya melaksanakan peran dan keterampilan edukasional bagi masyarakat diantaranya Membangkitkan kesadaran masyarakat (Consciousness Raising), Pemberian/ menyampaikan informasi (Informing), Konfrontasi (Confronting), dan Pelatihan (Training) (Adi, 2013; Ife, 2006). Lebih lanjut agar peran institusi Pendidikan tinggi dapat berjalan efektif, harus memiliki kemampuan, motivasi, dan kesiapan dimanapun berada untuk menyediakan layanan Pendidikan yang berkualitas (Havemen dan Smeeding, 2006).

Dalam hal bantuan berbasis pengetahuan, peran institusi Pendidikan tinggi menekankan pada sistem pembelajaran dan kapasitas sebagai bagian dari strategi pengetahuan yang lebih luas, dan ada pergeseran kearah membangun pengetahuan pada tingkat yang berbeda dari sebelumnya (sistem, kelembagaan, organisasi, individu). Dalam penelitian ini, Desa Cibuntu yang merupakan Desa Wisata yang terletak di Kecamatan Pasawahan Kabupaten Kuningan telah mengembangkan pariwisata berbasis komunitas sehingga mengantarkan Desa Cibuntu mendapatkan penghargaan peringkat dua tingkat Nasional dalam ajang Indonesian Sustainable Tourism Awards (ISTA) kategori Community Based Tourism yang diselenggarakan pada tahun 2017, juga mendapatkan penghargaan peringkat lima tingkat ASEAN dengan kategori yang sama. Keberhasilan ini tidak terlepas dari peran institusi Pendidikan tinggi yang menyediakan layanan pendidikan bagi komunitas Desa Cibuntu, dan komunitas berhak akan layanan tersebut. Sebagaimana penuturan bahwa selain pemerintah nasional dan lokal, peserta Pendidikan lain diantaranya siswa dan keluarga, swasta, dan juga komunitas termasuk 
didalamnya. (World Bank, 2011; Rita van Deuren, 2013).

Dengan demikian seyogyanya komunitas tidak bisa terlepas dengan institusi Pendidikan. Pernyataan yang menggambarkan komunitas tidak terlepas dengan institusi pendidikan juga diperkuat dengan pendapat Anthony D. Cortese (2003) yang menguraikan bahwa ruang lingkup praktek umum pendidikan tinggi mencakup pendidikan, penelitian, operasi universitas, dan komunitas/ masyarakat eksternal, dalam gambar berikut:

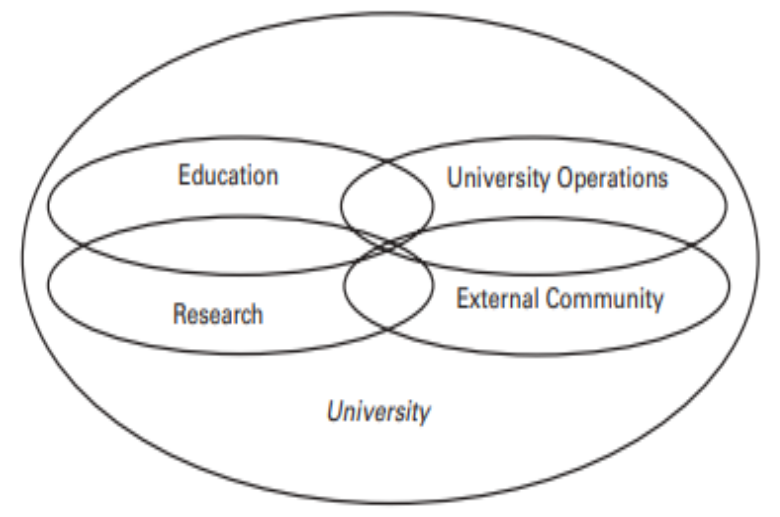

Society \& Biosphere

Gambar 1. General Practice of Higher Education

Dengan demikian, institusi Pendidikan tinggi memikul tanggungjawab besar untuk memberikan kontribusi dalam pengelolaan urusan sampai dengan pemecahan berbagai masalah yang ada dilingkungan komunitas atau masyarakat, termasuk dipenelitian ini dalam pengembangan pariwisata berbasis komunitas di Desa Cibuntu. Pendidikan dapat dikatakan memiliki ruang lingkup yang luas sebagai pendekatan pemecahan masalah sosial, permasalahan pada sektor pariwisata termasuk dapat dilakukan dengan menggunakan pendekatan berbasis edukasi. Sebagaimana terdapat hasil penelitian oleh Burcin dkk. (2014) tentang metodologi untuk pendidikan dalam pariwisata berkelanjutan yang menguraikan pentingnya peran pendidikan tinggi mempersiapkan warga dan tenaga professional dalam menciptakan ekonomi, sosial, dan lingkungan berkelanjutan. Ini juga sekaligus sebagai tantangan bagi institusi Pendidikan tinggi seberapa jauh institusi Pendidikan tinggi mampu merespon secara keseluruhan terhadap konteks yang lebih luas berupa kondisi krisis ketidakberlanjutan dan peluang untuk mengupayakan keberlanjutan tersebut (Sterling, 2004).

Atas pendekatan CBT yang dilakukan komunitas Desa Cibuntu dalam pemecahan permasalahan, pariwisata berbasis masyarakat atau dalam istilah yang lebih popular dikenal dengan Community Based Tourism (CBT) merupakan salahsatu pendekatan pengembangan pariwisata dengan menekankan masyarakat sebagai inisiator dan pelaku utama, sebagaimana pendapat bahwa pengembangan berbasis komunitas mengedepankan komunitas sebagai pelaku utama dari pembangunan (Chaskin, 2001; Maulana, 2013).

Selanjutnya Suansri (2003, pg. 14) mendefinisikan CBT sebagai pariwisata yang memperhitungkan aspek keberlanjutan lingkungan, sosial dan budaya. CBT merupakan alat pembangunan komunitas dan konservasi lingkungan, atau dengan kata lain CBT merupakan alat untuk mewujudkan pembangunan pariwisata yang berkelanjutan.

Sebagai pendekatan yang menekankan pada masyarakat sebagai unsur utama, CBT merupakan salahsatu pendekatan partisipatif masyarakat dalam pembangunan pariwisata. Salahsatu kunci utama dalam keberhasilan pembangunan pariwisata berbasis masyarakat atau CBT adalah partisipasi aktif pihak-pihak yang terlibat didalamnya termasuk stakeholder yang bermitra dengan komunitas tersebut. Dengan kata lain, dalam konteks menjalin kerjasama yang baik, 
kemitraan perlu menjadi bagian penting dalam pembangunan pariwisata oleh masyarakat.

Konsep CBT yang diterapkan dalam pengembangan pariwisata oleh komunitas Cibuntu mendatangkan keberhasilan karena komunitas melibatkan partisipasi dari semua unsur baik internal maupun eksternal dengan melibatkan unsur institusi Pendidikan tinggi. Praktik pengelolaan destinasi wisata bukanlah hal yang mudah, demikian dibutuhkan kolaborasi dengan pemangku kepentingan terkait yang mampu memberikan pengetahuan dan informasi dalam industri pariwisata (Rodolfo Baggio and Chris Cooper, 2010). Menurut pandangan peneliti peran dalam pemberian informasi kemungkinan dekat dengan peran seorang pendidik atau hanya mungkin akan lebih efektif dilakukan oleh institusi Pendidikan tinggi.

Merujuk pada uraian diatas sangat memungkinkan masuknya institusi pendidikan tinggi kedalam struktur komunitas dalam peningkatan kapasitas komunitas di urusan pariwisata berbasis komunitas. Mengingat pentingnya peran institusi pendidikan yaitu terjadinya transfer pengetahuan bagi komunitas.

Memrujuk pada uraian diatas sebagian besar telah banyak temuan membahas mengenai kapasitas komunitas dalam pengembangan pariwisata. Namun penelitian yang lebih rinci dengan fokus melibatkan peran institusi pendidikan tinggi bagi kapasitas komunitas dalam pengembangan pariwisata berbasis komunitas tidak ditemukan penelitian yang relevan. Dengan demikian penulisan artikel ini hendak menyediakan kerangka awal yang menguraikan bahwa institusi pendidikan dan entitasnya memiliki peran penting untuk meningkatkan kapasitas komunitas dalam hal ini masyarakat perdesaan dalam konteks pengembangan pariwisata berbasis komunitas, bagi pihak-pihak yang berkepentingan terutama ditingkat pengambilan keputusan, sekaligus diharapkan dapat mendorong dilakukannya penelitian selanjutnya dengan indikator yang lebih luas dan mendalam.

\section{METODE PENELITIAN}

Penelitian mengenai peran institusi pendidikan tinggi bagi kapasitas komunitas Desa Cibuntu dalam pengembangan pariwisata berbasis masyarakat ini menggunakan pendekatan kualitatif dengan jenis penelitian deskriptif, bertujuan untuk untuk memberikan gambaran dengan menggunakan kata-kata dan angka serta untuk menyajikan profil (persoalan), atau garis besar tahapan guna menjawab pertanyaan seperti siapa, kapan, dimana dan bagaimana (Newman, 2013).

Desa Wisata Cibuntu dipilih menjadi lokasi penelitian karena merupakan satu-satunya Desa Wisata yang ada di Kabupaten Kuningan dan mendapatkan penghargaan tingkat Nasional dan tingkat Asia Tenggara. Pemilihan informan dalam penelitian ini menggunakan teknik purposive sampling, dengan kriteria sebagai berikut (Newman, 2006): 1) pemberi informasi harus mengetahui keadaan lingkungan yang akan diteliti, 2) pemberi informasi harus berpartisipasi aktif dilapangan, 3) seseorang yang dapat meluangkan waktunya untuk penelitian, dan 4) individu yang tidak memiliki pola pikir analisis, karena seorang pemberi informasi yang non-analis sangat familiar dengan teori adat istiadat atau norma. Dengan demikian informan yang terlibat dalam penelitian ini, mencakup pihak Pemerintahan Desa Cibuntu, Kelompok Penggerak Pariwisata, Pengelola Homestay dan masyarakat Desa Cibuntu. 
Tabel 2. Kriteria Informan

\begin{tabular}{|c|c|c|c|c|}
\hline \multirow{2}{*}{\multicolumn{2}{|c|}{$\begin{array}{ll}\text { Informasi } \\
\text { A. } & \text { Peningkatan/ } \\
\text { membangkitk } \\
\text { an kesadaran } \\
\text { masyarakat } \\
\text { (Consciousne } \\
\text { ss Raisino) }\end{array}$}} & \multicolumn{2}{|c|}{ Kriteria Informan } & $\begin{array}{c}\text { Juml } \\
\text { ah }\end{array}$ \\
\hline & & $\begin{array}{l}\text { Pemerint } \\
\text { ahan } \\
\text { Desa } \\
\text { Cibuntu }\end{array}$ & $\begin{array}{l}\text { Perangkat } \\
\text { Desa }\end{array}$ & 1 \\
\hline B. & $\begin{array}{l}\text { (Consciousne } \\
\text { ss Raising) } \\
\text { Pemberian/ } \\
\text { menyampaika } \\
\mathrm{n} \text { informasi } \\
\text { (Informing }\end{array}$ & $\begin{array}{l}\text { Pengelol } \\
\text { a Desa } \\
\text { Wisata } \\
\text { Cibuntu }\end{array}$ & $\begin{array}{l}\text { Kelompok } \\
\text { Penggerak } \\
\text { Pariwisata } \\
\text { (Kompepar) }\end{array}$ & 3 \\
\hline C. & $\begin{array}{l}\text { Pelatihan } \\
\text { (Training) }\end{array}$ & $\begin{array}{l}\text { Masyara } \\
\text { kat Desa } \\
\text { Cibuntu }\end{array}$ & $\begin{array}{l}\text { Masyarakat } \\
\text { penerima } \\
\text { manfaat }\end{array}$ & 5 \\
\hline
\end{tabular}

Pengumpulan data dilakukan melalui metode wawancara mendalam, observasi dan studi literatur yang relevan. Teknik Analisa data dilakukan melalui tiga tahapan yaitu yaitu data reduction (reduksi data), data display (penyajian data), dan conclution drawing/ verification (penggambaran kesimpulan/ verifikasi) (Huberman, 1984).

\section{HASIL PENELITIAN}

Berdasarkan hasil temuan lapangan, kapasitas komunitas Desa Cibuntu lebih mengarah atau berkaitan dengan pengambilan keputusan untuk tindakan pencegahan terhadap dampak negatif dan lebih jauh untuk menciptakan kesejahteraan masyarakat Desa Cibuntu. Keberhasilan komunitas Desa Cibuntu dalam pengembagan pariwisata berbasis komunitas dilihat berdasarkan pihak-pihak yang terlibat dapat dibagi menjadi dua, yaitu faktor internal dan faktor eksternal. Faktor internal menunjukkan pihak yang secara langsung terlibat dalam pembangunan pariwisata yaitu seluruh elemen masyarakat Desa Cibuntu mencakup pemerintahan Desa, Kompepar (Kelompok Penggerak Pariwisata, Pengelola Homestay dan masyarakat Desa Cibuntu secara umum). Dalam proses pengembangan wisata di Desa Cibuntu didukung oleh keterlibatan aktif semua unsur masyarakat Desa Cibuntu. Masyarakat Desa Cibuntu memegang peran sesuai dnegan keahliannya di bidang masing-masing dan bagian tertentu dibagi berdasarkan kelompok usia. untuk para ibu-ibu terlibat dalam pengelolaan homestay, pemuda dan pemudi terlibat dalam beberapa kegiatan seperti kompepar, karangtaruna, pendamping ataupun kelompok kesenian untuk menyambut tamu/ pengunjung, terlibat dalam tim marketing wisata Desa Cibuntu, ada yang berpartisipasi sebagai guide, para pemuda terlibat dalam karang taruna, ada yang terlibat sebagai penerjemah apabila ada tamu asing yang berkunjung. Karena sebelumnya pernah mendapat kunjungan tamu yang berasal dari Jerman dan Thailand.

Sedangkan salahsatu pihak eksternal yang terlibat dalam proses pembangunan yaitu Institusi Pendidikan Tinggi. Melalui peran pendidikan tinggi ini diharapkan dapat menciptakan dan memimpin upaya berkelanjutan bagi Komunitas melalui keterlibatan aktif dengan melakukan pembinaan. Pihak akademisi yang dianggap mumpuni secara keilmuan atau orang yang tepat di bidang yang tepat akan membantu dalam pemecahan masalah, termasuk permasalahan dalam pembangunan pariwisata di Desa Cibuntu. Berdasarkan hasil temuan, berikut peran yang dilakukan institusi pendidikan tinggi bagi Komunitas Cibuntu.

Peran Institusi Pendidikan Tinggi bagi Komunitas Desa Cibuntu

1) Peningkatan Kesadaran 
Penelitian tahun 2011 oleh Tim Pascasarjana Trisakti yang terdiri atas Dosen dan mahasiswa pascasarjana menemukan hasil identifikasi bahwa Cibuntu memiliki potensi luar biasa untuk dijadikan destinasi dan Desa Wisata. Temuan ini disampaikan kepada masyarakat Cibuntu terutama kepada pimpinan Pemerintahan Desa Cibuntu dan jajarannya untuk membangun kesadaran mereka karena pada saat itu belum terbentuk Kelompok penggerak pariwisata. Demikian, menggambarkan Institusi Pendidikan Tinggi Trisakti telah melakukan perannya pada tahap pertama yaitu upaya meningkatkan kesadaran Komunitas Pariwisata dalam memanfaatkan potensi yang terdiri atas potensi alam yaitu area wisata Gunung terdiri atas wisata hutan, taman nasional, dan bumi perkemahan, goa, cagar budaya, situs sejarah dan museum serta potensi air terjun, dengan area wisata gunung merupakan area wisata terluas yang dimiliki Desa Cibuntu.

Temuan penelitian lain yang dilakukan mahasiswa dari Institusi Pendidikan Tinggi Trilogi Jakarta terkait cara menanam tanaman Strowberry dan cara perawatannya. Keberhasilan temuan mahasiswa dari Institusi Pendidikan Trilogi ini membuat Komunitas Desa Cibuntu mengambil langkah menempatkan 1orang dari mahasiswa tersebut untuk mengurus perawatan strawberry di Desa Cibuntu. Kini kebun strawberry menjadi salahsatu ikon wisata di Desa Cibuntu.

\section{2) Pemberian Informasi}

Desa Cibuntu memegang teguh prinsip keterbukaan/open minded yaitu membuka diri terhadap bentuk masukan, disiplin ilmu apapun, dan informasi apapun yang bersifat membangun selalu ditampung oleh Komunitas Desa Cibuntu. Tujuan dari prinsip keterbukaan diri, karena
Komunitas Desa Cibuntu memiliki keinginan dan tekad untuk maju.

Prinsip tersebut kemudian diterapkan bagi kemajuan Desa Cibuntu dengan menerima informasi membangun dari insitusi pendidikan Tinggi. Pendidikan tinggi dalam proses ini melakukan upaya pendekatan sosialisasi kepada masyarakat, memberikan pengarahan terkait dengan pelayanan homestay, mencakup kebersihan rumah, pengadaan tempat sampah, pengadaan kapstok, kaca, meja, lemari dan lainnya. Sebagai mitra utama dengan komunitas Desa Cibuntu, dalam hal pemberian informasi, Kelompok Penggerak Pariwisata Desa Cibuntu selaku pelaksana dan pengelola wisata di Cibuntu mendapatkan arahan dari Sekolah Tinggi Pariwisata Trisakti Jakarta, informasi untuk tujuan pengembangan masyarakat tersebut kemudian disampaikan kepada Komunitas Desa Cibuntu.

\section{3) Konfrontasi}

Masyarakat Desa Cibuntu hidup dalam ruang gotong royong dan kekerabatan yang sangat tinggi, sehingga hal-hal atau tindakan-tindakan yang bersifat frontal atau membutuhkan penanganan serius akibat tindakan keliru masyarakatnya sampah sejauh ini tidak pernah terjadi, sehingga Institusi Pendidikan Tinggi yang terlibat di Desa Cibuntu tidak perlu melakukan tindakan konfrontasi.

\section{4) Pelatihan}

Pelatihan adalah peran yang banyak dilakukan Institusi Pendidikan yang terlibat dalam pengembangan Desa Wisata Cibuntu. Pembinaan yang dilakukan Institusi Pendidikan Tinggi bagi Komunitas Desa Cibuntu dapat dibagi menjadi 2 kategori yaiu pembinaan secara langsung dan tidak langsung. Pembinaan secara langsung merupakan bentuk pelatihan yang diberikan oleh tim dosen/ pascasarjana kepada Komunitas Cibuntu secara 
tatap muka. Pembinaan secara tidak langsung yaitu bentuk evaluasi / laporan yang berasal dari mahasiswa yang sedang melakukan Kuliah Kerja Nyata di Desa Cibuntu. Adapun daftar Institusi Pendidikan Tinggi yang terlibat dalam pemberian pelatihan kepada Komunitas Desa Cibuntu diantaranya Sekolah Tinggi Pariwisata Trisakti Jakarta, Universitas Indonesia, dan, dan Universitas Tujuh Belas Agustus Cirebon.

Pemberian pelatihan oleh institusi pendidikan tinggi Trisakti diprioritaskan untuk meningkatkan lifeskill masyarakat Desa Cibuntu agar masyarakat merasakan bahwa setelah berubah status menjadi Desa Wisata, masyarakat dapat berpartipasi aktif dalam proses pengembangan dan mendapatkan manfaat secara ekonomi. Aspek ekonomi ini penting menjadi perhatian, karena ini merupakan hal sensitif yang menimbulkan kesenjangan/ kecemburuan diantara masyarakat.

Jenis pelatihan yang diberikan dengan sasaran Kelompok Penggerak Pariwisata Desa Cibuntu diantaranya terkait dengan tema konservasi, paket wisata, seni budaya, dan kuliner. Pelatihan yang diberikan kepada pemandu berkaitan dengan tema guiding untuk memberikan pelayanan yang baik kepada pengunjung yang datang ke homestay. Pelatihan dengan sasaran pengelola homestay diantaranya cara melipat bedcover, cara merapikan tempat tidur, cara menerima tamu, cara melakukan reservasi, cara menyiapkan makan, pengadaan fasilitas yang harus tersedia seperti sandal capit, tempat sampah, kapstok, cermin, meja, dan kursi, serta pelatihan terkait cara mengemas satu produk kuliner yang akan disajikan kepada pengunjung di stand-stand. Selain pelaksanaa kompepar, guide dan pemilik homestay, komunitas apapun Desa Cibuntu yang berkaitan dengan pengembangan pariwisata Desa Cibuntu akan mendapatkan prioritas pelatihan.
Institusi pendidikan tinggi lain yang pernah turut serta terlibat dalam memberikan pelatihan yaitu dari Univeristas Indonesia, Dosen dari Universitas Indonesia ini memberikan pelatihan tentang kepurbakalaan dan cara merawat kekayaan budaya tersebut. Selanjutnya Sekolah Tinggi Pariwisata Trisakti Jakarta dan Univeristas Tujuh Belas Agustus Cirebon memberikan pelatihan terkait pengembangan Agricotourism berbasis Organic Agriculture dalam peningkatan daya saing.

Atas peran yang dilakukan oleh Instansi Pendidikan tersebut memberikan implikasi positif bagi kapasitas Komunitas Desa Cibuntu dalam pengembangan pariwisata yang dilakukan berbasis masyarakat Desa Cibuntu itu sendiri.

Implikasi Peran Institusi Pendidikan Tinggi bagi Kapasitas Komunitas Desa Cibuntu dalam Pengembangan Pariwisata berbasis Masyarakat

\section{1) Peningkatan Kesadaran terhadap Sense of Community}

Komunitas merasa ada keterikatan untuk mengembangkan Desa Cibuntu. Siapa lagi yang mau peduli kalo bukan masyarakat Cibuntu itu sendiri. Rasa kepemilikan diantara ruang masyarakat Desa Cibuntu terlihat dari budaya gotong-royong, budaya kekeluargaan yang sangat tinggi diantara komunitas Desa Cibuntu.

\section{2) Peningkatan Kesadaran terhadap Level of}

\section{commitment among community member}

Melakukan pertemuan/ koordinasi dengan semua tingkat masyarakat; aparat desa, rt/rw, kompepar, tim marketing, kelompok PKK, kelompok tani, kelompok ternak, dan masyarakat secara umum. Tujuannya untuk menampung masukan, ide, menuju satu pemikira yang sama. Targetnya kedepan semakin timbul kesadarankesadaran dan dukungan dari masyarakat. 
Komitmennya bahwa apa yang ada di Cibuntu, dari, oleh dan untuk masyarakat Cibuntu itu sendiri pada akhirnya. Masyarakat Cibuntu yang peduli, melakukan pembenahan dan pengembangan, maka manfaatnya juga harus terasa oleh semua masyarakat Cibuntu.

Komitmen memberikan pelayanan terbaik kepada tamu/ pengunjung, pelayanan fisik, pelayanan material, pelayann fasilitas, terutama pelayanan etika, pengelolaan homestay, sehingga muncul kesan positif dari pengunjung.

\section{3) Peningkatan Kesadaran terhadap the ability to solve prolem}

Komunitas melakukan perbaikan terusmenerus terkait perencanaan (hal yang kurang pas), selanjutya dari inventarisir hal-hal yang kurang dibuat yang sifatnya untuk jangka pendek, jangka menengah, dan jangka panjang. Konsep yang diterapkan Komunitas Cibuntu sederhana, mengalir apa adanya, mengikuti perkembangan, melaksanakan yang pada saat tersebut terlihat dan merasa mampu, berangkat dari hal-hal kecil.

Merealisasikan inovasi baru berupa unit usaha (memberikan kesibukan di masing-masing wilayah) yang bertujuan agar semua masyarakat Desa Cibuntu terlibat dalam pengelolaan dalam unit usaha tersebut. Sekaligus sebagai upaya pemecahan masalah atas munculmya kesenjangan, gap, kecemburuan diantara beberapa masyarakat yang merasa belum mendapatkan manfaat secara materil Desa Cibuntu.

Memprioritaskan dan mengarahkankan anak muda; a) Memberikan prolog, menyampaikan maksud dan tujuan kegiatan, b) Merangsang berfikir anak muda untuk mengambil tanggungjawab, berkarya di tanah mereka sendiri, sehigga tidak perlu merantau ke luar Kota.

\section{4) Peningkatan Kesadaran terhadap Acces to resources}

Akses sumberdaya yang paling penting dan menjadi tantangan bagi Desa Cibuntu adalah sumberdaya manusia itu sendiri; a) Melakukan pengumpulan dan invenatrisir data sosial kependudukan Desa Cibuntu, b) Identifikasi potensi sumberdaya manusia, berdasarkan usia, jenis kelamin, keahlian, pengalaman, dan minat akan keterampilan tertentu, c) Memetakan hasil identifikasi potensi sumberdaya manusia, dan d) Mengembangkan masyarakat baik hardskill maupun softskill berdasarkan pemetaan diatas.

$$
\text { Bertambahnya kesadaran kelompok }
$$
masyarakat untuk rumahnya menjadi anggota homestay, dari 2011 hanya berjumlah 16 homestay sampa saat ini menjadi 60 homestay dengan 110 jumlah kamar. Karena masyarakat yang pada akhirnya ikut bergabung, melihat dari pengalaman dan manfaat yang dirasakan dari 16 itu, seperti adanya kunjungan tamu. Alasan masyakat yang awalnya enggan bergabung karena adanya rasa malu dengan kondisi rumah mereka, akhirnya rasa malu tersebut kini berubah jadi rasa percaya diri. Bukan tentang kondisi da nisi fasilitas rumah, melainkan pelayanan yang baik yang diutamakan.

\section{5) Pemberian Informasi terhadap terhadap Level of commitment among community member}

Komunitas Desa Cibuntu berkomitmen memberikan hak masyarakat atas manfaat yang didapat dari aktifitas pariwisata. Kesejahteraan masyarakat adalah hal yang menjadi perhatian utama. Contoh Komunitas tidak berani bayar telat ke masyarakat homestay, begitu pendapatan masuk ke Komunitas, segera dibayarkan ke pemilik homestay.

\section{6) Pemberian Informasi terhadap the ability to solve prolem}

Komunitas Desa Cibuntu dapat mengatur pusat kegiatan usaha, seperti pengelolaan warungwarung yang dipusatkan di satu tempat dengan jumlah yang dibatasi. 


\section{7) Pelatihan terhadap Sense of Community}

Hal utama yang menarik bagi Institusi Pendidikan Tinggi dari Desa Cibuntu yaitu kearifan lokal masyarakatnya. Sehingga Pendidikan Tinggi memberikan pelatihan yang menekankan pada pelayanan etika. Manajemen terkait desa wisata tidak sesederhana manajemen objek wisata, masyarakat sebagai modal utama. Objek wisata dipandang memilik tugas yang sudah pasti, sedangkan desa wisata selalu dinamis dengan masyarakat sebagai basisnya. Implikasi pelatihan menguatkan rasa diantara Komunitas Desa Cibuntu dalam pengelolan pariwisata di Desanya.

\section{8) Pelatihan terhadap Level of Commitment among Community Member}

Komunitas Desa Cibuntu mampu

melakukan pembagian secara merata kunjungan tamu grup yang akan menggunakan jasa homestay. karena tidak setiap kunjungan grup dapat memenuhi secara penuh 60 homestay yang tersedia, bisa jadi setengahnya yaitu 30 homestay. Maka untuk kunjungan grup kedepannya diberikan kepada homestay yang sebelumnya belum mendapat bagian. Aturan rotasi ini berlaku untuk mewujudkan pemerataan bagi masyarakat Cibuntu.

\section{9) Pelatihan terhadap acces to resources}

Komunitas melakukan pembagian kerja dalam rangka menyambut kunjungan tamu grup terkait dengan tempat untuk memasak dan menyajikan konsumsi, pembagian peran siapa saja yang menyediakan konsumsi dan sebagainya.

Berdasarkan gambaran diatas, dapat dirangkum hasil implikasi peran institusi Pendidikan tinggi bagi kapasitas komunitas Desa Cibuntu dalam tabel berikut:

Tabel Simpulan Implikasi Peran Institusi Pendidikan

Tinggi dalam pengembangan kapasitas komunitas

$\begin{array}{ccccc}\text { Peran } & \begin{array}{c}\text { Implikasi } \\ \text { of } \\ \text { Pendidik } \\ \text { Commu } \\ \text { nity }\end{array} & \begin{array}{c}\text { Level of } \\ \text { commitment } \\ \text { among } \\ \text { community } \\ \text { member }\end{array} & \begin{array}{c}\text { the } \\ \text { ability } \\ \text { to solve } \\ \text { prolem }\end{array} & \begin{array}{c}\text { Acces } \\ \text { to } \\ \text { resour }\end{array} \\ \begin{array}{c}\text { Peningkatan } \\ \text { Kesadaran } \\ \text { Memberikan } \\ \text { Informasi } \\ \text { Pelatihan }\end{array} & \checkmark & \checkmark & \checkmark & \checkmark \\ & - & \checkmark & \checkmark & - \\ \end{array}$

\section{PEMBAHASAN}

Merujuk pada temuan penelitian, kapasitas Komunitas Desa Cibuntu dalam pengembangan pariwisata di desanya menggambarkan kemampuan, usaha dan hasil dari apa yang telah dilakukan oleh masyarakat/ Komunitas Desa Cibuntu untuk mencapai tujuan awalnya yaitu mengembalikan Cibuntu menjadi seperti sedia kala sebagaimana kondisi awal yang hijau, asri, sejuk dan nyaman sebelum terjadinya penggalian lahan secara besar-besaran yang telah meninggalkan kerusakan lingkungan alam dan lahan Desa Cibuntu. Menunjukkan komunitas Cibuntu meningkatkan kemampuan diri untuk mencapai tujuan (Gandara, 2008). Nampak bahwa yang dilakukan oleh komunitas Desa Cibuntu berupaya meningkatkan kapasitas dan kualitas diri untuk merespon dengan cepat atas perubahan lingkungan yang terjadi. Senada dengan pendapat bahwa pengembangan kapasitas sebagai sebuah proses untuk mempengaruhi, atau menggerakkan, perubahan di berbagai tingkatan (multi-level) pada individu, kelompok, organisasi dan sistem yang berusaha memperkuat kemampuan adaptasi diri dan organisasi sehingga mereka dapat merespon perubahan lingkungan yang terjadi secara terusmenerus (Morrison, 2001).

Komunitas Desa Cibuntu selaku tuan rumah Desa Cibuntu merasa memiliki kewajiban untuk menata, memperbaiki, menjaga kelestarian lingkungan alam mereka. Kapasitas masyarakat menunjukkan fungsi, mengidentifikasi dan memecahkan masalah, menetapkan dan mencapai 
kebutuhan, peluang, dan sasaran (Milen, 2006; Sakiko etc., 2002). Senada dengan pendapat bahwa kapasitas komunitas adalah pengaruh gabungan dari komitmen komunitas, sumber daya dan keterampilan yang dapat digunakan untuk membangun kekuatan komunitas dan mengatasi masalah dan peluang komunitas (Aspen Institute, 2000; Liou: 2004).

Merujuk pada temuan penelitian, prakteknya peran institusi pendidikan tinggi bagi masyarakat Cibuntu dalam hal ini masih terdapat beberapa kelemahan, seperti berikut:

a. Terdapat tim dosen yang dikirim suatu instansi pendidikan tinggi untuk memberikan pelatihan merasakan bahwa keilmuan mereka tidak sesuai kebutuhan dan permasalahan masyarakat di Desa Cibuntu. Ini menimbulkan pertentangan bathin, namun sebagai bentuk tugas dan kewajiban, kegiatan tetap dilanjutkan. Pada akhirnya tim akademisi ini mengambil kegiatan mengajar apa saja yang bisa dikerjakan, seperti mengajar suling, mengajar kaligrafi.

b. Terdapat praktisi bidang "Desa Wisata" yang menyampaikan masukan bahwa terdapat sedikit kekeliruan masyarakat dalam menangkap konsep tentang Desa Wisata. Desa Wisata identik dengan nuansa alami, bersih, nyaman, dengan fasilitas khas perdesaan seperti alat tidur dari dipan, hihid (kipas yang terbuat dari bambu). Namun kenyataannya saat ini kondisi homestay untuk ukuran di perdesaan terbilang mewah dengan springbed yang bagus-bagus dan tebal. Karena konsep yang selama ini dipakai erat dengan ilmu/ manajemen perhotelan. Ini jelas keliru untuk konsep untuk desa wisata. Saat ini jika ada pengunjung yang betul-betul menginginkan suasana yang alami,
Komunitas Desa Cibuntu tidak bisa menyediakan.

Berdasarkan kelemahan diatas, yang prioritas dibutuhkan Komunitas Desa Cibuntu saat ini adalah praktisi dengan kelimuan yang sesuai dengan kebutuhan dan permasalahan yang dihadapi Komunitas Desa Cibuntu. Sebagaimana pendapat bahwa minat teoritis dalam memahami proses transfer pengetahuan dalam sistem yang kompleks seperti tujuan wisata sangat penting dari sudut pandang praktisi (Baggio and Cooper, 2010). Menurut pandangan peneliti menempatkan orang yang tepat untuk pemecahan permasalahan berdasarkan keilmuan yang tepat akan sangat bernanfaat karena akan mudah mengidentifikasi permasalahan dan memberikan pemahaman yang baru bagi Komunitas Desa Cibuntu untuk memecahkan masalah tersebut.

Berdasarkan kelemahan tersebut, kriteria praktisi Pendidikan yang diharapkan komunitas Cibuntu yaitu orang yang memiliki jiwa sosial yang tinggi, mau berbagi ilmu, dan sungguhsungguh memiliki keinginan membantu Desa Cibuntu. Komunitas Desa Cibuntu juga memberi kelonggaran, praktisi tidak harus terikat dan tidak harus selalu standby di Cibuntu, yang penting memiliki target yang jelas dan komunikasi aktif dapat dilakukan secara berkelanjutan dengan memanfaatkan aplikasi yang mendukung. Senada bahwa pengembangan kapasitas komunitas memerlukan interaksi yang intensif dari komponen-komponen kapasitas komunitas (Andini, 2013), salahsatunya mencakup Interorganizational Collaboration (Chaskin, 2001).

Untuk kategori praktisi yang hanya bisa menyempatkan diri memberikan pelatihan satu kalipun dinantikan Komunitas Desa Cibuntu dengan syarat konten yang disampaikan relevan 
dengan kebutuhan dan permasalahan yang dihadapi Desa Cibuntu. Sebagaimana pendapat bahwa analisis pemangku kepentingan adalah alat yang membantu suatu pemahaman tentang bagaimana operator mempengaruhi penciptaan dan penyebaran informasi dalam suatu tujuan dan kebijakan dan kegiatan yang dihasilkan. Ini sangat berguna dalam menyoroti tantangan yang perlu dihadapi untuk mengubah perilaku manajemen pengetahuan, kemampuan dan mengatasi masalah. (Baggio and Cooper, 2010).

Temuan mengemuka mengenai keberhasilan kapasitas komunitas Desa Wisata Cibuntu menggerakkan masyarakat atas adanya keterlibatan stakeholder terutama dengan Institusi Pendidikan Tinggi dalam pengembangan pariwisata berbasis masyarakat. Pariwisata tidak terlepas dari jejaring. Jaringan sangat umum terdapat dalam sektor jasa dan banyak dari institusi berada dalam jejaring terlibat dalam pariwisata (Bickerdyke, 1996; Pamungkas, 2013). Lembaga atau struktur eksternal seperti institusi Pendidikan tinggi nyatanya bisa dilibatkan dalam keanggotaan pengembangan kapasitas komunitas, sebagai proses untuk menjamin kesinambungan/ keberlanjutan melalui pencapaian tujuan (Grindle, 1997). Sebagaimana pendapat World Bank bahwa institusi pendidikan dapat masuk kedalam struktur masyarakat karena pendidikan milik semua lapisan masyarakat, bukan hanya masyarakat yang dibatasi oleh ruang lingkup institusi pendidikan melainkan masyarakat secara luas yang juga perlu mendapatkan pendidikan (World Bank, 2011; Rita van Deuren, 2013). Selanjutnya kapasitas atau kapabilitas harus diciptakan sebelum tujuan ditentukan, hal ini untuk memastikan budaya, sistem organisasi kemampuan dan pemahaman mengenai sumberdaya manusia dapat dikejar dalam jangka panjang (Sloman, 1997).

\section{1) Peran Institusi Pendidikan Tinggi dalam Peningkatan Kesadaran}

Berdasarkan hasil temuan penelitian, memgungkapkan telah terjadinya peningkatan kesadaran komunitas Desa Cibuntu bahwa mereka memiliki potensi luar biasa untuk dapat mengembangkan pariwisata, terutama dari sisi sumber daya alam. Dalam hal ini institusi Pendidikan tinggi berhasil membangkitkan titik penting pada masyarakat yaitu kesadaran komunitas Desa Cibuntu dalam membangun desanya melalui pariwisata melalui potensi yang mereka miliki, senada dengan uraian bahwa mengembangkan kapasitas dan potensi individu dan organisasi yang ada dimasyarakat penting terhadap pembangunan manusia yang berkelanjutan (UNDP, 1997).

Peran dimana pendidik melakukan tindakan agar terjadinya peningkatan kesadaran dengan memberikan kesadaran terhadap berbagai struktur dan strategi perubahan sosial sehingga orang-orang dapat berpartisipasi dan mengambil tindakan efektif. Peningkatan kesadaran penting untuk membantu masyarakat melihat kekurangan mereka dan bagaimana mereka bisa mendirikan berbagai struktur oleh diri mereka sendiri. Kapasitas masyarakatlah yang dianggap mampu mengatasi kekurangan pada diri mereka sendiri (UNDP, 1997). Terkadang hal ini bisa dilakukan dengan hanya membantu orang-orang untuk memberi tahu berbagai cara yang bisa mereka gunakan untuk mengubah kehidupan mereka sendiri (Jim Ife, 2008).

Kesadaran dalam mengembangkan pariwisata dari masyarakat dan untuk masyarakat tidak bisa dianggap sebagai hal yang mudah. Awal kesadaran komunitas Desa Cibuntu tidak dapat didefiniskan secara jelas bentuknya, namun kesadaran komunitas ini yang menjadi sasaran 
utama dalam membangun priwisata Desa Cibuntu. Institusi Pendidikan tinggi dalam hal ini sebagai penggagas ide tidak hanya dihadapkan pada kendala meyakinkan masyarakat secara luas dalam mendukung implementasi pembangunan pariwisata berbasis masyarakat, namun awalnya sulit untuk meyakinkan pimpinan pemerintahan desa, yang sempat mendapat penolakan bahwa menjadikan Cibuntu sebagai desa wisata merupakan hal yang mempertaruhkan nama Desa, Pemerintahan Desa, juga masyarakat Desa. Sampai pada akhirnya komunitas Desa Cibuntu menyadari mereka memiliki kepentingan yang sama dan sangat memahami bahwa gerakan masyarakat sendirilah sebagai modal dasar yang akan mewujudkan tujuan yang diharapkan dalam pembangunan pariwisata. Sebagaimana pendapat bahwa masyarakat adalah sekelompok orang yang memiliki perasaan sama atau menyatu satu sama lain karena mereka saling berbagi identitas, kepentingan-kepentingan yang sama, perasaan memiliki dan biasanya satu tempat yang sama (Suharto, 2010). Pendapat senada mengungkapkan bahwa komunitas adalah sekelompok orang hidup bersama, berkembang menjadi sebuah kelompok yang diikat oleh kesamaan kepentingan/ common interest (Syahyuti, 2005; Maulana: 2013).

Berdasarkan temuan, teridentifikasi bahwa peran peningkatan kesadaran berimpikasi dalam meningkatkan kapasitas komunitas Desa Cibuntu mencakup sense of community, level of commitment among community member, ability to solve problem, dan acces to resouces dalam pengembangan pariwisata berbasis komunitas, yang berarti peran institusi Pendidikan telah mampu memunculkan rasa kepemilikan diantara sesama komunitas Desa Cibuntu. Rasa kepemilikan sebagai modal utama dari jejaring pengelolaan pariwisata (Pamungkas, 2013). Selain itu meningkatkan komitmen komunitas Desa Cibuntu untuk peduli, melakukan pembenahan dan pengembangan, dan menciptakan manfaat yang dirasakan oleh komunitas. Dari sisi acces to resources, kapasitas komunitas Desa Cibuntu mampu melakukan identifikasi potensi sumber daya manusia dan dan pengelolaan yang ditujukan untuk pengembangan hardskill dan softskill komunitas desa Cibuntu. Pengembangan kapasitas sebagai proses melalui yang mana individu, organisasi dan masyarakat dapatkan, memperkuat dan mempertahankan kemampuannya untuk menetapkan dan mencapai tujuan pembangunan mereka sendiri dari waktu ke waktu (UNDP, 2009).

Peningkatan kapasitas diatas nampak tidak hanya berdampak postif bagi komunitas Desa Cibuntu saja, tetapi lebih secara kelembagaan Desa Cibuntu, sebagaimana pendapat Sakiko (2002) pengembangan kapasitas dalam paradigma saat ini yaitu pengembangan sumberdaya manusia kombinasi dengan penguatan institusi atau lembaga tersebut.

\section{2) Peran Institusi Pendidikan Tinggi dalam Pemberian Informasi}

Berdasarkan temuan, teridentifikasi bahwa peran institusi Pendidikan tinggi dalam pemberian informasi berimpikasi dalam meningkatkan kapasitas komunitas Desa Cibuntu mencakup level of commitment among community member dan ability to solve problem. Pemberian informasi oleh institusi Pendidikan tinggi menjadikan komunitas Desa Cibuntu menjaga komitmen memenuhi hak masyarakat atas manfaat yang didapat dari pariwisata dan melakukan relokasi tempat usaha yang sebelumnya belum teratur sebagai upaya pengaturan kegiatan usaha dalam pengembangan pariwisata. Pengembangan pariwisata mampu berjalan oleh organisasi karena terbukti mendatangkan manfaat. Demikian, jejaring dianggap memiliki kapasitas untuk menyampaikan 
program/ informasi dari keadaan modal menjadi hasil (Pamungkas, 2013). Informasi penting disampaikan oleh pendidik, sebagai salahsatu peran pekerja masyarakat untuk menginformasikan orang-orang mengenai apa yang sedang terjadi dalam masyarakat (Jim Ife, 2008). Dalam hal ini peran seorang pendidik dalam lingkup komunitas mensyaratkan kemampuan menyampaikan informasi dengan baik dan jelas dan mudah ditangkap oleh komunitas serta mempunyai pengetahuan yang cukup memadai mengenai topik yang akan dibicarakan (Adi, 2012).

\section{3) Peran Institusi Pendidikan Tinggi dalam Pelatihan}

Berdasarkan hasil temuan penelitian, Institusi Pendidikan Tinggi telah menjalankan peran edukasional bagi komunitas Desa Cibuntu dalam pengembangan pariwisata berbasis komunitas melalui berbagai macam pelatihan dengan sasaran semua unsur komunitas Desa Cibuntu, karena dalam konteks pengembangan masyarakat pelatihan merupakan salahsatu program yang sering dilakukan untuk meningkatkan kapasitas klien/ capacity building (Suharto, 2010). Pelatihan juga sebagai salahsatu tipe kegiatan yang difokuskan untuk dimensi pengembangan sumberdaya manusia (Grindle, 1997), perhatian yang diberikan dalam konteks pengembangan sumberdaya manusia (Keban, 2000). Senada dengan penuturan diatas, Jim Ife (2008) pelatihan merupakan peran edukatif yang paling spesifik, karena hal tersebut melibatkan bagaimana mengajarkan masyarakat untuk melakukan sesuatu. Demikian juga dengan temuan bahwa peningkatan kapasitas dilakukan melalui kegiatan pendidikan baik formal maupun nonformal dan kegiatan penyuluhan/ pelatihan (Anantanyu, 2011), pihak ekseternal dalam pengelolaan pariwisata berperan dalam memberikan pendidikan dan pelatihan (Pamungkas, 2013).

Berdasarkan temuan, teridentifikasi bahwa peran pelatihan oleh institusi Pendidikan tinggi berimpikasi dalam meningkatkan kapasitas komunitas Desa Cibuntu mencakup sense of community, level of commitment among community member, dan acces to resources, yang berarti bahwa pelatihan oleh institusi Pendidikan tinggi telah menguatkan rasa komunitas Desa Cibuntu dalam pengembangan pariwisata dengan mengutamakan etika pelayanan yang baik kepada pengunjung. Selain itu pelatihan meningkatkan komitmen komunitas dalam melakukan pengelolaan dan pembagian jatah kunjungan tamu yang akan menggunakan jasa homestay secara merata kepada komunitas. Lebih luas pelatihan meningkatkan kapasitas komunitas dalam rangka pengelolaan tugas pokok dan fungsi, pembagian peran secara adil diantara komunitas dalam pengembangan pariwisata. Dapat melaksanakan kinerja pelaksanaan tugas pokok dan fungsi sebagai hasil dari proses peningkatan kapasitas (Milen, 2006). Terjadinya pembagian peran secara adil diantara komunitas, mengindikasikan fungsi pelatihan hampir selalu menjadi bagian dari fungsi terkait sumberdaya manusia (Sloman, 1997). Berdasarkan uraian diatas, peran pelatihan sangatlah luas cakupannya bagi komunitas Desa Cibuntu, sebagaimana semestinya peran dari pelatihan tidak seharusnya didefiniskan secara sempit (Sloman, 1997).

Upaya pelatihan diatas oleh institusi Pendidikan tinggi untuk komunitas Desa Cibuntu hendak mengarahkan sumber daya manusia menuju ke level yang lebih baik/ berkembang, yang berarti bahwa pengembangan pada dasarnya adalah transformasi sistem produksi dari masyarakat (Khalid Malik, 2002). Pengembangan melibatkan 
perubahan, peningkatan, dan vitalitas yang merupakan upaya yang diarahkan untuk meningkatkan partisipasi, fleksibilitas, kesetaraan, sikap dan fungsi institusi dan kualitas hidup (Christenson et al., 1989; Jim Ife, 2008).

Sebagaimana banyak program pelatihan yang diterapkan institusi Pendidikan tinggi untuk kapasitas komunitas Desa Cibuntu dalam pengembangan pariwisata berbasis komunitas, pelatihan mencakup program-program yang dibutuhkan untuk semua kelompok sasaran. Pelatihan yang diselenggarakan institusi Pendidikan tinggi bagi komunitas Desa Cibuntu dalam konteks urusan pariwisata berimplikasi positif dalam peningkatan kapasitas komunitas Desa Cibuntu. Senada dengan temuan Aref (2010) bahwa pelatihan dalam pengembangan kapasitas menjadi cara yang efektif, terlihat, dan bernilai tinggi untuk operasi pariwisata untuk berkontribusi pada pembangunan lokal.

Merujuk pada hasil diatas, nampak bahwa komunitas Desa Cibuntu berhasil dalam pengembangan pariwisata berbasis komunitas dilandasi karena adanya keterlibatan institusi Pendidikan tinggi. Dalam hal ini nampak bahwa keterlibatan peran Pendidikan tinggi berkontribusi positif dalam pengembangan kapasitas komunitas terkait dengan pemecahan masalah dan pengembangan dalam urusan pariwisata yang dihadapi komunitas Desa Cibuntu. Dalam hal ini, institusi Pendidikan tinggi telah menyediakan proses pembelajaran yang sesuai dengan kebutuhan pengembangan kapasitas komunitas Desa Cibuntu, dimana pengembangan kapasitas mencakup proses pembelajaran, akumulasi benturan yang menambah prospek untuk sumberdaya manusia agar secara terus menerus beradaptasi terhadap perubahan (Soeprapto, 2006).

Perlunya melibatkan institusi Pendidikan tinggi dalam menyediakan pembelajaran dalam konteks pengembangan kapasitas komunitas, demikian karena institusi pendidikan tinggi memiliki daya tarik tersendiri di mata masyarakat dalam mensosialisasikan sikap ilmiah. Disamping karena dipandang merupakan wadah dimana terdapat orang-orang yang memiliki kompetensi yang mumpuni dibidangnya dan dapat dipercaya karena mengutamakan penalaran, institusi Pendidikan tinggi menjadi daya tarik bagi masyarakat karena dipandang sebagai sumber pengejaran ilmu pengetahuan tingkat tinggi dan penguasaan teknologi yang sangat dibutuhkan bagi kemajuan dan kemakmuran suatu masyarakat (Kuntoro, 2001).

\section{SIMPULAN}

Peningkatan Kesadaran, Institusi

pendidikan tinggi berdasarkan hasil temuan penelitian memberikan gagasan membentuk Desa Wisata Cibuntu, ini sebagai upaya menyadarkan masyarakat bahwa Cibuntu memilliki potensi luar biasa untuk proses pembangunan pariwisata berbasis masyarakat. Memberikan informasi, Institusi pendidikan tinggi melakukan upaya pendekatan sosialisasi kepada masyarakat, memberikan pengarahan terkait dengan pengembangan wisata Desa Cibuntu.
Pelatihan.,Institusi pendiidkan tinggi melakukan pembinaan baik secara langsung maupun tidak langsung. Pembinaan langsung yaitu tim dosen secara tatap muka membina Komunitas Cibuntu, sedangkan laporan evaluasi/ hasil penelitian mahasiswa di Cibuntu sebagai bentuk pelatihan tidak langsung bagi komunitas Cibuntu. Pemberian pelatihan diprioritaskan untuk meningkatkan lifeskill masyarakat Desa Cibuntu agar masyarakat merasakan bahwa setelah berubah status menjadi Desa Wisata, masyarakat dapat berpartipasi aktif 
dalam proses pengembangan dan mendapatkan manfaat secara ekonomi. Semua hal yang berkaitan dengan pengembangan untuk pariwisata, maka pendidikan tinggi akan menyiapkan dan memberikan jenis pelatihan apapun untuk masyarakat Desa Cibuntu.

Implikasi peran institusi pendidikan tinggi bagi kapasitas komunitas Desa Cibuntu perlu adanya peningkatan kesadaran berimplikasi terhadap sense of community, level of commitment among community member, the ability to solve problem, dan access to resources, Pemberian informasi berimplikasi terhadap level of commitment among community member dan the ability to solve problem. Serta, Pelatihan berimplikasi terhadap sense of community, level of commitment among community member, dan access to resources.

Peningkatan kesadaran merupakan peran institusi pendidikan tinggi yang berimplikasi terhadap semua aspek kapasitas komunitas Desa Cibuntu.

\section{REKOMENDASI}

Menempatkan praktisi pendidikan yang sesuai dengan kebutuhan dan permasalahan utama yang dihadapi oleh komunitas untuk meningkatkan kapasitas komunitas dalam pengembangan pariwisata sebagai rekomendasi penting merujuk pada hasil penelitian. Selain itu, komunitas perlu untuk mendesain sejak awal terkait dengan peran institusi pendidikan dalam peran pengembangan pariwisata terutama tentang Desa Wisata yang manajemennya lebih kompleks.

\section{DAFTAR PUSTAKA}

Adi, Isbandi Rukminto. (2012). Intervensi Komunitas \& Pengembangan Masyarakat sebagai Upaya Pemberdayaan Masyarakat. Jakarta: PT. Rajagrafindo Persada.

Anantanyu, Sapja. (2011). Kelembagaan Petani: Peran dan Strategi Pengembangan Kapasitasnya. No. 2. Jurnal Fakultas Pertanian. Vol. 7 Tahun 2011.

Andelissa Nur Imran. (2012). Identifikasi Kapasitas Komunitas Lokal dalam Pemanfaatan Potensi Ekowisata bagi Pengembangan Ekowisata di Kawah Cibuni. Jurnal Perencanaan Wilayah dan Kota, Vol.23 No. 2, Agustus 2012, hlm. 85-102.

Andini, Nurulitha. (20013). Pengorganisasian Komunitas dalam Pengembangan Agro wisata di Desa Wisata; Studi Kasus Desa Wisata Kembangarum, Kabupaten Sleman. Jurnal Perencanaan Wilayah dan Kota. Vol. 24 No. 3 Tahun 2013, hlm. 173188.

Antonella Noya and Emma Clarence. (2009). Paper. Project Outline and Proposed Methodology.

Baggio, Rodolfo \& Cooper, Chris. (2010). Knowledge transfer in a tourism destination: the effect of a network structure. The service Industries Jurnal, Vol.30, n. 8,2010.

Beckley, Thomas, M., etc. (2008). Multiple Capacities, Multiple Outcomes: Delving Deeper into the Meaning of Community Capacity. Journal of Rural and Community Development.

Chaskin, Robert, J. (2001). Building Community Capacity: A Definitional Framework and Case Studies from a Comprehensive Community Initiative. Urban Affairs Review, Vol. 36, No. 3, January 2001, 291-323. University of Chicago. Sage Publications, Inc.

Cortose, Anthony, D. (2003). The Critical Role of Higher Education in Creating a Sustainable Future. Higher education can serve as a model of sustainability by fully integrating all aspects of campus life. Article Planning for Higher Education.

Deuren, Rita Van. (2013). Capacity Development in Higher Education Institution in Developing Countries. Working Paper No. 2013/30. Maastricht School of Management: Netherlands.

Education Sector Strategy Draft. (-). Learning for all: Inversting in People Knowledge and Skills to Promote Development. World 
Bank Education Strategy 2020 - draft for comment.

Fariborz Aref. (2010). Community Capacity as an Approach for Sustainable Tourism. EReview of Tourism Research (eRTR), Vol. 8, No. 2, 2010. Putra University, Malaysia.

Gandara, R. (2008). Capacity Building Dosen pada Jurusan di Perguruan Tinggi Badan Hukum Milik Negara. Skripsi Sarjana pada Fakultas Ilmu Pendidikan UPI Bandung: tidak diterbitkan.

Garrod, Brian. (2001). Local Participation in the Planning and Management of EcoTourism: A Revised Model Approach. Bristol: University of The West England.

Grindle, M.S., (editor). (1997). Getting Good Government: Capacity Building in the Public Sector of Developing Countries. Boston, MA: Harvard Institute for International Development.

Hatipoglu, Burcin., Ertuna, Bengi, \& Sasidharan, Vinod. (2014). A Referential Methodology for Education on Sustainable Tourism Development. Journal Sustainability.

Haveman, Robert, and Smeeding, Timothy. (2006). The Role of Higher Education in Social Mobility. USA: Princeton University.

Ife, Jim \& Tesoriero, Frank. (2008). Community Development: Alternatif Pengembangan Masyarakat di Era Globalisasi. Yogyakarta: Pustaka Pelajar.

Jaeik Liou. (2004). Community Capacity Building to Strengthen Socio-Economic Development with Spatial Asset Mapping. Third FIG Regional Conference, Jakarta, Indonesia, October 3-7, 2004.

Keban T. Yeremias. (2000). "Good Governance" dan "Capacity Building" sebagai Indikator Utama dan Fokus Penilaian. Jurnal Perencanaan Pembangunan, Jakarta.

Kuntoro, SA. (2001). Pendidikan dalam Perspektif Tantangan Bangsa: Kajian Pendidikan Sepanjang Hidup dalam Cakrawala Pendidikan. Mei 2001, Th XX, No. 2. Yogyakarta: Lembaga Pendidikan Pendidikan kepada Masyarakat UNY.

Maulana, Ihsan. (2013). Hubungan antara Potensi Kompetensi Komunitas dengan Kapasitas Komunitas pada Kelompok Usaha Tani Kecamatan Lembang, Kabupaten Bandung Barat. Jurnal Perencanaan Wilayah dan Kota. Vool. 24 No. 3 tahun 2013, hlm. 189-202.
Milen. (2006). Capacity Building: Meningkatkan Kinerja Sektor Publik. Yogyakarta: Pembaruan.

Miles, Mathew, B., \& Huberman A.M. (1984). Qualitative Data Analysis: A Method Sourcebook. London: Sage Publications.

Morrison, Terrace. (2001). Actionable Learning: A Handbook for Capacity Building Through Case Based Learning, Asian Development Bank Institute. Tokyo: ADBI Publishing.

Neuman, W. Lawrence. (2013). Metodologi Penelitian Sosial: Pendekatan Kualitatif dan Kuantitatif. Eds.7. Penerjemah: Edina T. Sofia. Jakarta: PT. Indeks.

Newman, W. Lawrence. (2006). Basic of Social Research: Qualitative \& Quantitative Approaches. Pearson Edition.

Okta Hadi Nurcahyono (2017). Kapasitas Komunitas Lokal dalam Pengembangan Pariwisata Perdesaaan. Jurnal Pendidikan, Sosiologi dan Antropologi Volume 1 No. 01 Tahun 2017.

Pamungkas, Gilang. (2013). Ekowisata Belum Milik Bersama: Kapasitas Jejaring Stakeholder dalam Pengelolaan Ekowisata (Studi Kasus: Taman Nasional Gunung Gede Pangrango). Jurnal Perencanaan Wilayah dan Kota. Vol. 24 No. 1 Tahun 2013, hlm. 49-64.

Pemerintah Kabupaten Kuningan. (2017). Kuningan Raih Penghargaan Community Based Tourism. [Online]. Tersedia: https://www.kuningankab.go.id/berita/kun ingan-raih-penghargaan-communitybased-tourism

Peter O'Meara., Chesters, Janice \& Han, Gil-Soo. (2004). Outside-looking in: Evaluating a Community Capacity Building Project. Rural Society, Volume 14, Number 2, 2004.

Riyadi Soeprapto. (2006). Pengembangan Kapasitas Pemerintah Daerah Menuju Good Governance. Jurnal Ilmiah Administrasi Publik, Volume IV (1), FIA UNIBRAW, Malang.

Sakiko, Fukuda-Parr, Carlos Lopes, and Khalid Malik. (2002). Capacity for Development; New Solutions to Old Problems. London: Earthscan Publication Ltd.

Sloman, Martyn. (1994). A Handbook for Training Strategy. Cambridge: University Press.

Sterling, Stephen. (2004). Chapter 5; Higher Education, Sustainability, and The Role of Systemic Learning. Netherlands: Kluwer Academic Publisher. 
Suansri, Potjana. (2013). Community Based Tourism Handkbook. Thailand: Responsible Ecological Social Tour Project.

Suharto, Edi. (2010). Membangun Masyarakat Mmeberdayakan Masyarakat; Kajian Strategis Pembangunan Kesejahteraan Sosial dan Pekerjaan Sosial. Bandung: Refika Aditama.

United Nations Development Program. (1997). Capacity Development. New York: One United Nations Plaza. 